\title{
CULTIVAR AFFECTS BROWNING SUSCEPTIBILITY OF FRESHLY CUT STAR FRUIT SLICES
}

\author{
Gustavo Henrique de Almeida Teixeira ${ }^{1 *}$; José Fernando Durigan ${ }^{1}$; Ben-Hur Mattiuz ${ }^{1}$; Ricardo \\ Elesbão Alves²; Timothy James O’Hare ${ }^{3}$ \\ ${ }^{1}$ UNESP/FCAV - Depto. de Tecnologia, Via de acesso Paulo Donato Castellane, s/n - 14 884-900 - Jaboticabal, \\ SP - Brasil. \\ ${ }^{2}$ Embrapa Agroindústria Tropical, C.P. 3761 - 60 511-110 - Fortaleza, CE - Brasil. \\ ${ }^{3}$ DPI\&F, Gatton Research Station, Locked bag 7, Mail service 437, Gatton, 4343 Qld, Australia. \\ *Corresponding author <teixeiragha@yahoo.com.br>
}

\begin{abstract}
Consumption of freshly-cut horticultural products has increased in the last few years. The principal restraint to using freshly-cut carambola is its susceptibility to tissue-browning, due to polyphenol oxidase-mediated oxidation of phenolic compounds present in the tissue. The current study investigated the susceptibility to browning of star fruit slices (Averrhoa carambola L.) of seven genotypes (Hart, Golden Star, Taen-ma, Nota-10, Malásia, Arkin, and Fwang Tung). Cultivar susceptibility to browning as measured by luminosity ( $\mathrm{L}^{*}$ ) varied significantly among genotypes. Without catechol $0.05 \mathrm{M}$, little changes occurred on cut surface of any cultivars during 6 hour at $25^{\circ} \mathrm{C}, 67 \%$ RH. Addition of catechol led to rapid browning, which was more intense in cvs. Taen-ma, Fwang Tung, and Golden Star, with reduction in L* value of $28.60 \%, 27.68 \%$, and $23.29 \%$, respectively. Browning was more intense in the center of the slices, particularly when treated with catechol, indicating highest polyphenol oxidase (PPO) concentration. Epidermal browning, even in absence of catechol, is a limitation to visual acceptability and indicates a necessity for its control during carambola processing. Care must be given to appropriate selection of cultivars for fresh-cut processing, since cultivar varied in browning susceptibility in the presence of catechol. Key words: Averrhoa carambola L., cathecol, polyphenol oxidase, minimally processed, fresh-cut
\end{abstract}

\section{A CULTIVAR AFETA A SUSCEPTIBILIDADE AO ESCURECIMENTO DE PEDAÇOS RECÉM CORTADOS DE CARAMBOLA}

\begin{abstract}
RESUMO: O consumo de produtos hortícolas minimamente processados tem aumentado nos últimos anos. Entretanto, a principal restrição para o uso de carambolas minimamente processadas é sua susceptibilidade ao escurecimento devido a oxidação de compostos fenólicos presentes nos tecidos que é mediado pela polifenoloxidase (PPO). Investigou-se a suscetibilidade ao escurecimento de fatias de carambola (Averrhoa carambola L.) de sete cultivares (Hart, Golden Star, Taen-ma, Nota-10, Malásia, Arkin e Fwang Tung). A suscetibilidade das cultivares ao escurecimento, medido através da luminosidade (L*), variou significativamente entre cultivares. Sem a aplicação do catecol (0,05 M), ocorreram poucas mudanças de coloração na superfície cortada dos pedaços das diferentes cultivares durante 6 horas a $25^{\circ} \mathrm{C}, 67 \%$ U.R. A adição de catecol levou ao rápido escurecimento, que foi mais intenso nas cvs. Taen-ma, Fwang Tung e Golden Star, com redução no valor de L* de 28,60\%, 27,68\% e 23,29\%, repectivamente. O escurecimento foi mais intenso no centro dos pedaços, particularmente quando tratados com catecol, indicando grande atividade da PPO. O escurecimento da epiderme, mesmo na ausência de catecol, é uma limitação visual à aceitação e indica a necessidade de seu controle durante o processamento da carambola. Cuidados devem ser tomados quanto à recomendação de cultivares para o processamento mínimo, uma vez que estas apresentam variações quanto à susceptibilidade ao escurecimento na presença de catecol.

Palavras-chave: Averrhoa carambola L., catecol, polifenoloxidase, minimamente processado, fresh-cut
\end{abstract}

\section{INTRODUCTION}

The star fruit (Averrhoa carambola L.) is native of South-east Asia, has been disseminated to several regions of the world to become very popular (Wilson III, 1990; Nakazone \& Paull, 1998). The fruit is mainly consumed fresh but it has been increased interest in its potential for fresh-cut production, as they present an attractive star shape when sliced (Oslund \& Davenport 1983; Wilson III, 1990), to be used in salads, fruit salads and drinks, or as garnishing. 
However, one of the main problems of using fresh-cut slices is their susceptibility to browning resulting from oxidation of phenolic substrates, generally driven by polyphenol oxidase - PPO (Wiley, 1997). Fresh-cut star fruit slices brown during storage, losing their attractive yellow colour (Matthews, 1989; Matthews et al., 1989; Matthews \& Myers, 1995; Weller et al., 1995, 1997). This problem is exacerbated as a result of mechanical injury occurring along harvest, storage, and processing, and is mainly induced by the leakage of phenolic compounds from the vacuole, and subsequent oxidation by PPO (Augustin et al., 1985). Such injuries increase browning susceptibility of plant tissues, either through synthesis of phenolic compounds (Saltveit, 1999), or increased activity and/or solubility of PPO (Martinez \& Whitaker, 1995).

Many factors affect the shelf-life of fresh-cut slices including cultivar, ripeness at cutting, and storage conditions before processing (Sapers \& Miller, 1998; Gorny et al., 2002). According to Romig (1995), cultivars with reduced key enzyme activity are desired for minimal processing once enzymes which contribute to degradative processes, e.g., browning, softening, volatile generation, have demonstrated a range of activities depending on the genotype. The objective of this study was, thus, to evaluate browning susceptibility of different carambola cultivars on freshly sliced fruits.

\section{MATERIAL AND METHODS}

Plant material - Star fruits cvs. Hart, Golden Star, Taen-ma, Arkin, Fwang Tung, Nota 10, and Malasia selections were sampled from an experimental orchard in Bebedouro, São Paulo State, Brazil. Fruit were harvested when $50 \%$ of the fruit surface had developed a yellow or white colour. Harvest occurred in the morning, and fruits were immediately transported to

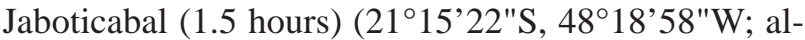
titude $595 \mathrm{~m})$.

Catechol treatment - Following initial washing and dipping in sodium hypochlorite solution (200 mg L $\left.{ }^{-1}\right)$ for 5 minutes, eight to ten fruits from each cultivar were transversely cut into slices approximately $0.7 \mathrm{~cm}$ thick. To establish the location of polyphenol oxidase a catechol solution 0.05 M (Sigma Corp. C-9510) or water (control) were applied to the surface of slices from different fruits according to Weller et al. (1995). Five drops of catechol solution were evenly spread over the cut surface of six slices per cultivar. Treated slices were then exposed to air under ambient conditions $\left(25^{\circ} \mathrm{C}, 67 \% \mathrm{RH}\right)$ for six hours.
Colour measurement - Colour of slices (two readings at the midpoint between endocarp and skin) was recorded immediately after catechol application (initial colour - 0 hour) and after 2, 4, and 6 hours of air exposure using a Minolta chromameter (Model CR 200b, Minolta, Osaka, Japan). The lightness ( $\left.\mathrm{L}^{*}\right)$ colour value was used as indicator of cut surface browning intensity (Weller et al., 1995). Change in L* value (ie. $\Delta \mathrm{L}$ ) between initial treatment (0 hour) and six hours was assessed as a browning indicator.

Statistical analysis - The trial was conducted according to a split split-plot design, with 7 genotypes (main plot; 'Hart', 'Golden Star', ‘Taen-ma', 'Arkin', 'Fwang Tung' 'Nota 10' and 'Malasia'), two treatments (subplot; control and catechol $0.05 \mathrm{M}$ ), and time (sub-subplot; $0,2,4$, and 6 hours) $(\mathrm{n}=6)$. Data were statistically analysed using SAS (1996).

\section{RESULTS AND DISCUSSION}

Untreated cultivar susceptibility to browning, as measured by lightness $\left(\mathrm{L}^{*}\right)$, varied significantly among cultivars, although initial colour varied immediately after cutting with 'Hart', 'Golden Star' and 'Fwang Tung' presenting the highest luminosity (Figure 1A). However initial differences in luminosity between cultivars were not related to browning, but to the inherent 'brightness' of the mesocarp tissue. Cvs. Fwang Tung, Hart and Golden Star are naturally lighter (white colour) than the yellow-orangish cultivars Taenma, Nota 10, Malasia and Arkin. Some Brazilian native star fruit trees did not differ in luminosity, though (Araújo \& Minami, 2001).

Upon exposure to room temperature, little change in luminosity occurred in all cultivars (Figure $1 \mathrm{~A}$ and 2A). These findings were similar to those observed for cultivars Arkin, Fwang Tung, Kary, Demak and selections WA 3-21-2, WA 3-22-36, WA 3-22-20, WA 3-22-3, WA 3-23-1 tested by Weller et al. (1995). These results indicate either reduced PPO activity or a limitation of oxidizing substrate.

Addition of catechol, however, led to rapid browning (Figure 1B), and indication that lack of substrate was possibly responsible for the lack of browning on the cut surface of the cultivars under evaluation. Results contrasts with those of Weller et al. (1995), who reported 'Fwang Tung' as having little reactivity towards catechol. The most rapid increase in browning was observed in cvs. Taen-ma, Fwang Tung and Golden Star (Figure 2B), which presented a reduction in $\mathrm{L}^{*}$ value of $28.60 \%, 27.68 \%$, and $23.29 \%$, respectively, in relation to zero hour. This trend would indicate higher potential PPO activity in these culti- 

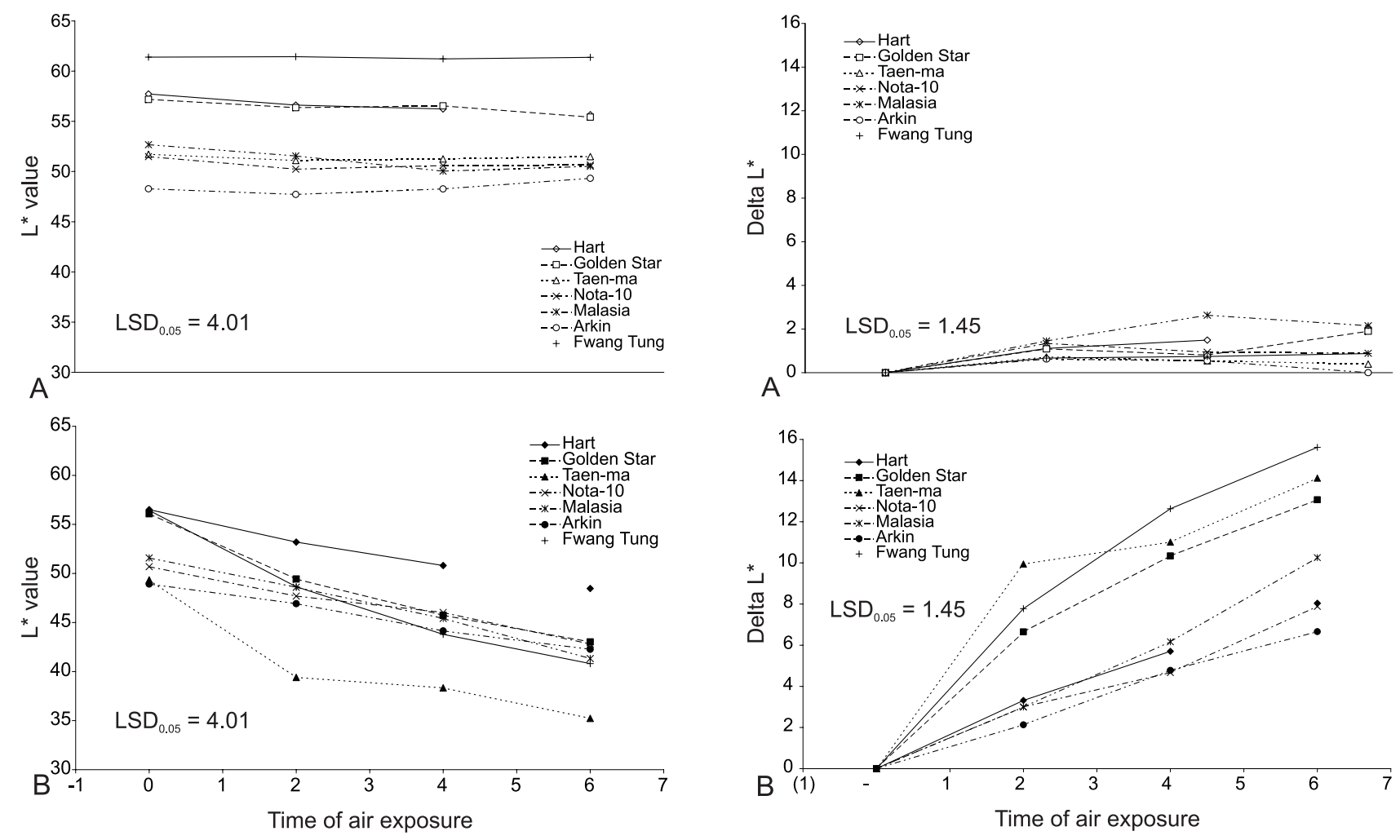

Figure 1 - Slices surface luminosity $\left(\mathrm{L}^{*}\right)$ of seven star fruit genotypes: (A) control and (B) catechol $0.05 \mathrm{M}$, after exposure to ambient conditions $\left(25^{\circ} \mathrm{C}\right.$ and $\left.67 \% \mathrm{RH}\right)$ for six hours.

vars. On the other hand, 'Arkin' and 'Hart' had just $13.81 \%$ and $14.23 \%$ decreases in during the same period, followed by 'Nota 10' and 'Malasia', 15.55\% and 19.87\%, respectively.

Browning was only observed when the $\mathrm{L}^{*}$ value fell below 43.8, and consequently only in slices where catechol had been applied (Figure 1B). Although not an issue in the current trial, it may indicate that cultivars with lower initial L* value (eg. Arkin) may be prone to browning under conditions where exogenous substrate may become available, such as in mixed salad preparation. According to Weller et al. (1997), 'Arkin' is one of the main commercial cultivars in Florida, and was one of the most susceptible to browning. Similarly, cultivars with high potential PPO activity (eg. Taen-ma and Fwang Tung) should also be watched, as they will reach this critical $\mathrm{L}^{*}$ value more rapidly. Based on the above, cv. Hart would be ideal for mixed salad preparation since it presents slightly browning and it is also considered to be a "sweet" type, originated from Malaysia.

When fresh-cut slices are packaged alone, it is unlikely that star fruit slices will be exposed to potential PPO substrates. Under these circumstances, cultivars developing the least amount of browning should

Figure 2 - Change in slice luminosity $(\Delta \mathrm{L})$ of seven star fruit genotypes: (A) control and (B) catechol $0.05 \mathrm{M}$, after exposure to ambient conditions $\left(25^{\circ} \mathrm{C}\right.$ and $\left.67 \% \mathrm{RH}\right)$ for six hours.

be used, and in the present trial all cultivars performed equally.

Even though browning tended to occur over the entire cut surface of star fruit slices, it was more intense in the middle of the slices, similarly to findings of Weller et al. (1995). This was particularly evident when slices were treated with catechol (Figure 3). Because of the difficulty of measuring luminosity of this tissue (due to small area), earlier measurements were made on the mesocarp in the current trial. This provided an indication of relative browning, but it should be stressed that browning of the cut epidermis layer and the endocarp present more obvious, and therefore quicker noticeable symptoms (Figure 3).

Vamos-Vigyazo (1981) reported that PPO location can vary between different fruit, and in tissues where there is no reaction to catechol, PPO is likely to be present in low concentration, or in a latent form, unresponsive to catechol. The latter, however, is less common in fruit (Amiot et al., 1997). On the other hand, higher PPO activity has been reported in apple at the core and near the skin, and from there the browning spreads over the cut surface, corresponding to the location of chlorogenic acid (Amiot et al., 1997). Gorny et al. (2002) also observed discoloration on the 


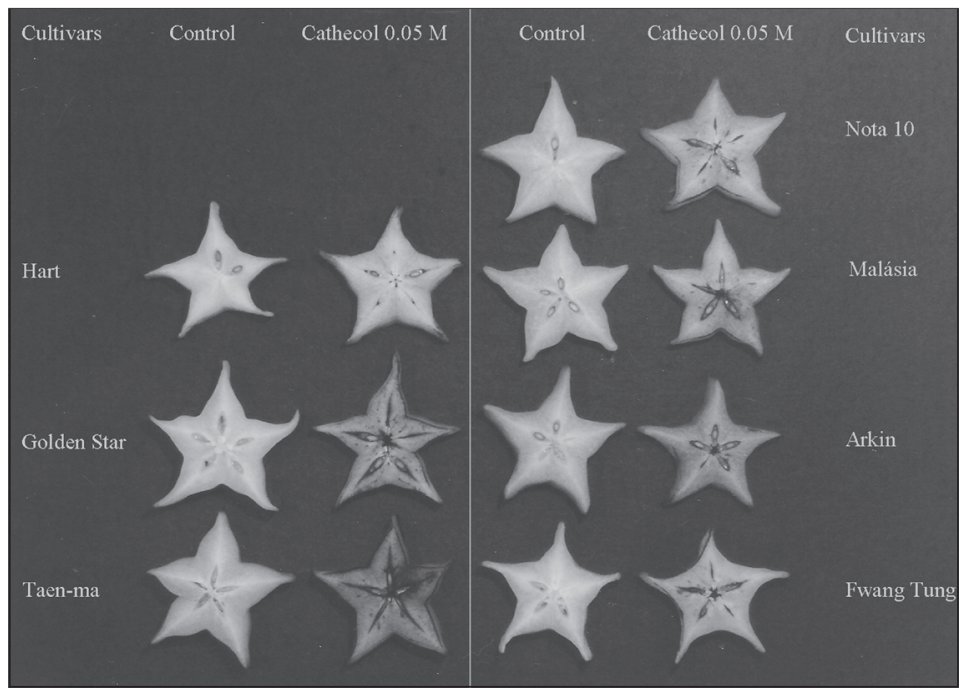

Figure 3 - Effect of catechol application on brown pigments development in slices of star fruit genotypes after exposure to ambient conditions $\left(25^{\circ} \mathrm{C}\right.$ and $\left.67 \% \mathrm{RH}\right)$ for six hours.

cut surface at the pear flesh/skin interface directly beneath the pear fruit epidermis (peel). The presence of browning in these parts may be due to the highest concentration of phenolic compounds (Van Buren, 1970). Whatever the case, without addition of exogenous catechol, browning of the epidermis and endocarp of star fruit slices did not significantly impact the luminosity of the surface area measured with a chromameter. This is undoubtedly due to the small area affected, but none the less a limitation to visual acceptability.

\section{ACKNOWLEDGEMENT}

The authors would like to thank the Fundação de Amparo a Pesquisa do Estado de São Paulo (FAPESP Proc. 00/13237-9) for sponsoring this research.

\section{REFERENCES}

AMIOT, M.J.; FLEURIET, A.; CHEYBIER, V.; NICOLAS, J. Phenolic compounds and oxidative mechanisms in fruit and vegetables. In TOMAZ-ARBERAN, F.A.; ROBINS, R.J. (Ed.). Phytochemistry of fruits and vegetables. Oxford: Clarendon Press, 1997. p.51-85.

ARAÚJO, P.S.R.; MINAMI, K. Seleção de caramboleiras pelas características biométricas e físico-químicas dos frutos. Scientia Agricola, v.58, p.91-99, 2001.

AUGUSTIN, M.A.; GHAZALI, H.M.; HASHIM, H. Polyphenoloxidase from guava (Psidium guajava L.). Journal of Science of Food and Agriculture, v.36, p.1259-1265, 1985.

GORNY, J.R.; HESS-PIERCE, B.; CIFUENTES, R.A.; KADER, A.A. Quality changes in fresh-cut pear slices as affected by controlled atmospheres and chemical preservatives. Postharvest Biology and Technology, v.24, p.271-278, 2002.

MARTINEZ, M.V.; WHITAKER, J.R. The biochemistry and control of enzymatic browning. Trends of Food Science and Technology, v.6, p.195-200, 1995.

MATTHEWS, R.F. Processing of carambola. In: INTERAMERICAN SOCIETY FOR TROPICAL HORTICULTURE, 33., Georgetown, 1989. Proceedings. Georgetown, 1989. p.83-90.
MATTHEWS, R.F.; MYERS, P.O. Effect of antioxidants on browning of refrigerated carambola slices. Proceedings of the Florida State Horticultural Society, v.108, p.316-320, 1995.

MATTHEWS, R.F.; LINDSEY, J.A.; WEST, P.F.; LEINART, A. Refrigerated vacuum packaging of carambola slices. Proceedings of the Florida State Horticultural Society, v.102, p.166-169, 1989.

NAKASONE, H.K.; PAULL, R.E. Tropical fruits. Wallingford: CAB International, 1998. 445p.

OSLUND, C.R.; DAVENPORT, T.L. Ethylene and carbon dioxide in ripening fruit of Averrhoa carambola. HortScience, v.18, p.229-230, 1983.

ROMIG, W.R. Selection of cultivars for lightly processed fruits and vegetables. HortScience, v.30, p.38-40, 1995.

SALTVEIT, M.E. Fresh-cut vegetables. In: BARTZ, J.A.; BRECHT, J.K. (Ed.). Postharvest physiology and pathology of vegetables. New York: Marcel Dekker, 1999. p.691-713.

SAPERS, G.M.; MILLER, R.L. Browning inhibition in fresh-cut pears. Journal of Food Science, v.63, p.342-346, 1998.

SAS INSTITUTE Inc. SAS User's guide: Statistics. Cary, 1996. 956p.

VAMOS-VIGYAZO, L. Polyphenol oxidase and peroxidase in fruits and vegetables. Boca Raton: CRC Press, 1981. p.49-127.

VAN BUREN, J. Fruit phenolics. In: HULME, A.C. (Ed.). The biochemistry of fruits and their products. London: Academic Press, 1970. p.269-304.

WELLER, A.; BATES, R.P.; MATTHEWS, R.F.; SIMS, C.A. Evaluation of carambola cultivars for the lightly processed marked. Proceedings of the Florida State Horticultural Society, v.108, p.320-324, 1995.

WELLER, A.; SIMS, C.A.; MATTHEWS, R.F.; BATES, R.P.; BRECHT, J.K. Browning susceptibility and changes in composition during storage of carambola slices. Journal of Food Science, v.62, p.256260, 1997.

WILEY, R.C. Métodos de conservación de las frutas y hortalizas mínimamente procesadas y refrigeradas. In: WILEY, R.C. (Ed.). Frutas y hortalizas mínimamente procesadas y refrigeradas. Zaragoza: Editorial Acribia, 1997. p.65-129.

WILSON III, C.W. Carambola and bilimbi. In: NAGY, S.; SHAW, P.E.; WARDOWSKY, F.S. (Ed.). Fruits of tropical and subtropical origin: composition, properties and uses. Lake Alfred: Florida Science Source, 1990. p.277-301.

Received May 23, 2005

Accepted November 04, 2005 